\begin{tabular}{|l|l} 
Dossıê & CONVERGENCE VS \\
& Rethinking the quality of TV News \\
$\begin{array}{r}\text { Copyright } \odot 2012 \\
\text { SBPjor } / \text { Brazilian } \\
\text { Association } \\
\text { of Journalism } \\
\text { Researchers }\end{array}$ & $\begin{array}{l}\text { BEATRIZ BECKER } \\
\text { Universidade Federal do Rio de Janeiro (UFRJ) }\end{array}$
\end{tabular}

\begin{abstract}
Wider audience participation, the hybridization of genres and formats, and transmediality, are the main features of today's communication processes. Convergence influences journalistic practice and imposes new ways of doing and thinking about television broadcasting. TV newscasts are still the highest-impact information products in the world. However, watching TV and accessing the internet are activities that are increasingly intertwined. The purpose of this study is to identify effects of the use of digital tools on the construction of the news and to verify whether they contribute to a higher quality audiovisual journalism and to a new way of writing the daily social experience. This study will present the results of a quantitative and qualitative analysis of the news of two vehicles of: the main private Brazilian communication group: Globo; the local television newscast RJTV; and the news portal G1. This paper featured in the Journalism Research and Education section, at the International Association of Media and Communication Research- IAMCR, Durban, South Africa, 2012.
\end{abstract}

Keywords: Convergence. Audiovisual journalistic narratives. Audiovisual quality journalism. Audiences. G1 and RJTV.

\title{
CONVERGENCE VS DIVERSITY: Rethinking the quality of TV News
}

RESUMO: A maior participação das audiências, a hibridização de gêneros e formatos e a transmidialidade são as principais características dos processos de comunicação na atualidade. A convergência influencia a prática jornalística e impõe novos modos de fazer e pensar o telejornalismo. Os noticiários televisivos ainda são os produtos de informação de maior impacto no mundo global, mas as atividades de ver TV e acessar a internet estão cada vez mais misturadas. O objetivo deste estudo é identificar efeitos de usos das ferramentas digitais na construção das notícias, questionar se essas mudanças contribuem para um jornalismo audiovisual de maior qualidade e para relações mais dialógicas com os telespectadores e usuários, a partir de um estudo de reportagens do telejornal local RJTV e do portal de notícias G1, produtos do maior grupo privado brasileiro de comunicação, as organizações Globo. Este trabalho foi apresentado na seção Journalism and Education Research (JRE), Internacional Association of Communication and Media Research - IAMCR, Durban, África do Sul, 2012.

Palavras-chave: Convergência. Narrativas jornalísticas audiovisuais. Jornalismo audiovisual de qualidade. Audiências. G1 e RJTV.

\section{CONVERGENCIA X DIVERSIDAD: Repensando la calidad de las noticias en la televisión}

RESUMEN: El aumento de la participación de la audiencia, la hibridación de géneros y formatos y la transmidialidade son las principales características de los procesos de comunicación actuales.La convergencia influye en la práctica periodística e requiere nuevas formas de hacer y de pensar las noticias de televisión. Noticieros de televisión siguen siendo los productos de información de mayor impacto en el mundo global, pero las actividades de ver TV y acceso a internet son cada vez más mezclados.El objetivo de este estudio es identificar los efectos de los usos de las herramientas digitales en la construcción de la noticia, cuestionando si estos cambios contribuyen a un periodismo de mejor calidad audiovisual y más relación dialógica con los espectadores y usuarios, a partir de un estudio de los informes del noticiero local RJTV y del portal de noticias G1, productos de comunicación del más grande grupo privado en Brasil, las organizaciones Globo. Este trabajo fue presentado en la sección Journalism and Education Research (JRE), Internacional Association of Communication and Media Research - IAMCR. Durban, Sudáfrica, 2012.

Palabras clave: convergencia. relatos periodísticas audiovisuales. periodismo audiovisual de calidad. audiencias. G1 y RJTV. 


\section{Introdution}

The current, mutant and dynamic processes of communication generated by convergence and the uses and adaptations of digital tools have caused uneasiness, expressed in research on different genres and languages at the present time, as well as in journalism. There is an emerging participatory culture in which the production of all the participating members nurtures and contributes in some way to the social connection between people (JENKINS, 2008; JENKINS et al., 2009). In the $21^{\text {st }}$ century, the concept of writing is being profoundly redefined based on the importance of technology, communication systems and the use of digital tools. This emergence can be noted due to the plurality of texts that circulate in different media and non-sequential writing, which functions as "an assemblage of network connections which, on permitting the requirement of a multiplicity of routes, transforms reading into writing"(MARTIN-BARBERO, 2011, p.132). Thus, the geographic configuration of the text organizes less and less the reader's activity and requires that his attitude be more and more active, which can result in more dialogical relations between production and reception (CERTEAU, 1996; FLUSSER, 2010). In addition, the very fact that the computer or video screen is a new, less restricted by linguistic conventions, in which verbal discourse is not subject to the same rules and regulations as the written press, "makes it the most appropriate and instrument for reinventing the acts of writing and reading" (MACHADO, 2003, p. 219220). Most likely, there is a move towards an interactive way of writing as a new form of multimedia language is developing, which also means rethinking the value of orality ${ }^{1}$ and the voices present and absent in a particular speech in communication processes, the effects of which as a cultural and political phenomenon are still difficult to measure, even in journalism studies and practices.

There are changes taking place in production routines and ways for developing the news. However, while in journalistic practices there are tendencies towards integration of the newsrooms (SALAVERRÍA and NEGREDO, 2009; DOMINGO et al, 2007), there still exist few news portals that incorporate multimedia resources in the construction of their reports on Brazilian information sites. Journalistic reports that utilize audio and video have been developed in languages and hybrid models of production, circulation and consumption of information termed "audiovisual journalism practices" because, at present, there is still a process at play involving mutual influence in the construction 
of TV journalism narratives and audiovisual web journalism (BECKER, 2009; BECKER and LIMA, 2007; BECKER and TEIXEIRA, 2009b; BECKER and MATEUS, 2011). Although the use of digital tools on television and the internet provide citizens not only with the possibility of interacting with the texts, but also of producing information and other meanings and representations regarding everyday social experience, this does not always generate more diverse audiovisual journalistic narratives of everyday social life in national and worldwide coverage (BECKER and MALDONADO, 2011; BECKER and MATEUS, 2010; BECKER and TEIXEIRA, 2009a). The main objectives of this study are to ascertain whether the present mixture of languages and in the development of local news has effectively provided a higher quality audiovisual journalism (BECKER, 2009), and to identify ways in which relations with audiences are established in these communication processes that are enhanced by convergence in the experience of participatory culture. It is questioned whether convergence has really favored the production of more plural journalistic reports and more dialogical relations between journalists and television viewers and users, by means of a comparative analysis of news production on television and the internet, specifically, on the local newscast RJTV $1^{\text {st }}$ edition and on G1, Globo's news portal (http:// g1.globo.com/). The latter are products of the largest private, Brazilian communication group.

The references consulted in this quantitative and qualitative study include contributions from the critical theory of discourses, cultural studies, television analysis, media literacy and journalism theories, not just studies of participatory journalism ${ }^{2}$, but also newsmaking. Traquina (2005) reveals that in studies on agenda-setting, the criteria for newsworthiness made up of news values, utilized by journalists in choosing events and developing the news, have acquired considerable importance in research undertaken in recent decades. These criteria are relevant to the evaluation of the aforementioned audiovisual journalistic narratives on television and the web, such as the criterion of visuality which (TRAQUINA, 2005), associated with thematization - a form of selection which focuses attention and public interest on certain topics and values rather than others (VILCHES, 1995) - is adopted as an important guideline for this analysis. Empirical research was carried out in three stages: a description of the two journalistic products studied; analysis of the audiovisual material; and interpretation (BECKER, 2012a). To this end, three relevant elements for achieving the intended results have been taken into consideration: identification of the percentages and origins of 
audiovisual contents made available on $\mathrm{G} 1$; evaluation of the division by sections of the stories disseminated both on the newscast as well as the site, observing the main news formats, topics covered and space given to contents produced by television viewers and users; and analysis of the forms of audience participation in the first editions of RJTV and G1. The corpus is made up of 14 recorded editions of the televised newscast, broadcast from October 15 to 31, 2011, amounting to almost 9 hours of audiovisual material, and audiovisual news production from the G1 portal. The search was done by section, that of Rio de Janeiro (http:// g1.globo.com/rio-de-janeiro/), and by date, indicating the specific period on the site. However, in order to deepen the analysis, the reflection proposed here requires rethinking the notions of dialogue and discourse, as well as television and participatory journalism.

\section{A storehouse of ideas and reflections}

For Flusser (2007), human communication and the processes of signification denote a struggle for the survival of the species, by means of the accumulation of information acquired from generation to generation, which in complex societies is no longer kept only as individual memories, but rather deposited in outside the human body, such as books or virtual databases. In order to produce information, humans exchange different available information in the hope of synthesizing new information. That is the form of dialogical communication (idem). For the dialogue to exist, the information from earlier discourses needs to be available to both participants. Each dialogue can be considered a series of discourses guided by the exchange. Thus, discourse is shaped and constrained by social structure but at the same time contributes to the constitution of all the dimensions of this structure. It is a situation where power struggles are waged and may be revealed, as well as a mode of representation and signification of the world, a form of action in which people can act on social relations and the others (FAIRCLOUGH, 2001). Every discourse can be considered part of a dialogue, as dialogue and discourse are intertwined. But participating in a discourse as a social practice of dispute senses, in which the reader plays an active role collaborating for conservation or for social transformation, is different from participating in a dialogue. Never before in the history of civilization has communication functioned in such an extensive and intensive fashion as it does today. However, perhaps there have never been so many occasions on which the accumulation of information has not resulted in dialogues, the 
construction of new information by means of exchange and knowledge, or in more diverse and plural perceptions of everyday social life. On the contrary, there is a prevalence of dominant discourses which often make dialogue impossible or unnecessary because they tend to become redundant (FLUSSER, 2009). But if humans become individually incapable of creating new information, a new meaning of "creativity" emerges in the dialogical production of information in the current transition, from an alphabetical culture to new forms of life and thought processed by digital codes (idem).

In fact, dialogue as a perspective for seeking truth and knowledge has always been a relevant issue since Ancient Greece. Bakhtin explains that the Socratic dialogue is a specific type, based on the Socratic conception of the dialogical nature of truth, in which syncrisis and anacrisis are the two fundamental procedures ${ }^{3}$. Bakhtin (2006) states that dialogue is the simplest and most classical form of discursive communication, a form of participation in which a polyphonic work such as that of Dostoiévski presupposes a group of men whose voices resound with the same intensity, without one dominating another (BAKHTIN, 2002). This notion of discursive polyphony implies a confrontation between broader social discourses, and it is by means of this confrontation that the author expresses the contradictions of the era (STAM, 1992). For Bakhtin (2002), dialogism is the constitutive principle of language, which is characterized by coexisting polemical voices in a discourse. Stam (1992) explains that Bakhtin's entire work revolves around the axis of I and the other, or between many "I's" and many others, and that the process of self-understanding occurs by means of the otherness in the exchange of experiences, views and sensitivities. The $\mathrm{I}$ is constructed via collaboration, though this process can be impeded by social forces because language is a social battlefield. In his work, Bakhtin presents a philosophy of language that is also a set of ethics and the basis for a literary method of analysis. Language results from verbal interaction, whose product is enunciation, which does not exist outside the socio-ideological context. Every enunciation proposes a rejoinder and, according to Bakhtin, there lies the construction of meaning in our responsive attitude, by means of the relation between the interlocutors. The polyphonic novel results from different social voices that confront each other upon manifesting different points of view without the presentation of a perfect truth, which is only possible due to comprehension of the real unit of discursive communication, the enunciation, a link in the chain of discursive communication full 
of echoes and resonances of other enunciations with which it is linked by the identity of the discursive sphere (BAKTHIN, 2006). For Bakhtin (idem), the study of the nature of enunciations and discursive genres is of fundamental importance in overcoming the simplified conceptions of "discursive flow", of communication, suggesting that each field of the utilization of language develops its own, relatively stable types of enunciations, which are called genres of discourse with infinite wealth and diversity (ibidem).

\section{Rethinking television}

The definition of the concept of discursive genre proposed by Bakhtin (2006) is utilized in the analysis of the dialogical interactions between the production and audiences in this study of audiovisual journalistic narratives because, as Machado (2003) outlines, it is a flexible, consistent theory adaptable to analyses of the contemporaneous audiovisual scene. As the author explains, it could perhaps seem an exaggeration to say that there are Socratic dialogues today in television but it would be wrong to disregard the fact that narratives mediated by radio and television emphasize strategically dialogue and the receiver's participation in their enunciations, while giving direction to and limiting audience participation. Machado (2003) suggests that a second phase of orality is unfolding, mediated by recording and transmission technologies provided by radio and television, considering that the discourses of the technological systems affect sensitivities and awareness. Clearly, television is the most characteristic of the mass media, and according to Scolari (2009), it is the most important communicational experience of the $20^{\text {th }}$ century, approached in different ways. However, the author suggests that viewers are witnessing another phase of television, hypertelevision, the configuration of a socio-technical network around it, associated with interactivity (SCOLARI, 2009), and, probably, a third phase of orality marked by interactions mediated by computers and the internet, in the virtual environment. The specificity of TV is no longer found in the linear extension of the stories, but in an expansion in different media (idem, p. 189). It is possible to notice the appearance of new characters in the serials in an increasingly polyphonic structure, and the trend toward a mixture of reality and fiction in the narratives. The most active, current reader would be what Scolari (2009) calls the transmedia consumer, who processes and integrates representations coming from different media and languages, highlighting the audiences' relevant role in the 
processes of constructing meanings. For Scolari (2009), "a new type of televised consumption is emerging, characterized by a fragmented, ubiquitous and asynchronous reception: a different program on each screen at the same time" (SCOLARI, 2009, p. 197). However, the author recognizes the coexistence in the current televised environment of old and new television forms, in which hybrid formats also multiply. In this way, studies of television and any other means of communication, are becoming increasingly isolated as they are not interpreted in the context of media ecosystems (SCOLARI, 2009).

Today, most of the news contents and formats made available on the network that incorporate audiovisual language and multimedia resources still suffer from the influence of televised narratives. At present, television is still the main source of news for most American adults (58\%), while the internet and mobiles are the preferred media among young people (PAVLIK, 20112 ). Brazil is no different. Television is spread across practically the entire national territory and is firmly established as the main source of information and entertainment for most of the population. In the programming grid of the open television stations, TV newscasts occupy strategic places because they construct the experience of social life, sell credibility and attract financial resources (BECKER, 2005). Televised newscasts still concentrate the largest amounts of advertising investments in their commercial breaks, including local TV newscasts. In order to place a 30 second advertisement on RJTV, the local newscast of the largest Brazilian open TV station, Globo Network, advertisers have to pay $\mathrm{R} \$ 111,100.00$ (US\$55,697.604) and on Jornal Nacional, the newscast with the largest audience in the country, they have to pay $\mathrm{R} \$ 507,000.00$ (US $\$ 253,829.98^{5}$ ) to insert an advertisement of the same length, making it the most expensive commercial break in the programming ${ }^{6}$. The Brazilian television audience has shown stable behavior in the last five years, accounting for more than half of the country's advertising investments, a total of 16.2 billion reals ( 8.1 billion dollars) between January and February $2011^{8}$. In this context, newscasts are still the information products with the greatest impact on society, and they continue to be important in contemporary media discourses (BECKER, 2005). Based on these considerations and the contributions of the authors mentioned, which constitute a storehouse of ideas and reflections that support this research, it follows that in studies on communication and journalism, analysis cannot be carried out without dealing with three distinct, complementary dimensions: 1) evaluating the processes of signification generated in a medium seeking interrelations 
with other media in the media environment, in a specific socio-economic and cultural context; 2) taking into account both the form as well as the content of the messages in understanding their dynamic constructions of meanings; and 3) observing the interaction between production and reception. The study is conducted from this perspective and, in order to obtain the intended results, studies of participatory journalism are also fundamental references.

\section{Journalism and audience}

There has been a trend towards a transition from the journalistic model of gatekeeping, the means of selection and news construction by journalists at the peak of the era of media without direct participation from the audiences, whose interests and reactions are extended and assumed by the journalists, to the practice of gatewatching in the production of news, establishing fairer relations between journalists and readers - users

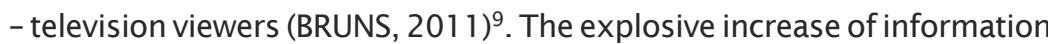
on a worldwide scale requires journalists also to offer information interacting with the collaborative curation of the news by communities of users who encounter, share, comment on and disseminate news. The collective effort to seek out, select and construct news in multiple sources involving a multitude of users with diverse interests, can result in higher quality journalistic coverage with greater diversity of topics and a larger number of stories, capable of bringing about broader perceptions of events (BRUNS, 2011). These processes have attracted the attention of journalism researchers and their works are important because they make it possible to understand that the incorporation of citizens' voices in news production is carried out in different ways and on distinct levels of complexity (HERMIDA, 2011; QUANDT, 2011). However, this practice does not always facilitate the advancement of democracy or the practice of a more pluralistic journalism, or of the decentralization of news choice and the way to deal with it, a professional activity performed exclusively by journalists for decades. With the emergence of digital technologies, journalists have begun to take part in a large network without the same privilege or hierarchy in selecting, editing and diffusing news, but they still retain the canvassing and authority to decide what is newsworthy (HERMIDA, 2011). Most of the opportunities users have to contribute to news production appear at the end of news production process through comments or debates on social networks regarding the contents developed by journalists. In fact, participatory journalism is not 
a simple technological process, but rather the result of the interaction between journalists and users, and is supposed to provide a platform for voices that are outside the media, such as those of co-workers. Nevertheless, journalists express reservations about user participation in news production, despite recognizing the journalistic value of a more active audience (HEINONEN, 2011). Thus, there is a strained relationship between the benefits of opening up journalistic production and the need to preserve the profession, and the power of large media groups. Studies on participatory journalism point out that current relations with audiences undermine the journalists' status and require scrutiny of their practice and professional training. However, most of them concentrate on the practices of online journalism. There is still a lack of literature devoted to studying how relations are established between production and reception in television and integrated newsrooms (SALAVERRÍA and NEGREDO, 2009; RAMOS, 2010). Also, the study of these processes by means of empirical research can contribute to elucidating these interactions in audiovisual journalistic narratives and, specifically in this study, on RJTV $1^{\text {st }}$ edition and the G1 portal, the local newscast and information site of the largest Brazilian communication business organization.

\section{Study of RJTV and G 1}

G1 and RJTV are examples of TV journalism's adoption of the trend of producing hyper-local news in the digital environment, produced by participating citizens from different communities (PAVLIK, 2011). RJTV is a newscast relevant to the construction of ties with the audience in the programming grid of the TV station, which is interested in expanding the audience through providing services for the community and the search for solutions to problems faced by the dwellers in different districts through denunciation and demands for government action, attributing to the newscast the power to resolve conflicts in its mediations.

The implementation of recent esthetic and technical experiments - new scenarios, more accelerated rhythms of presentation and editing influenced by immediatism and the speed of the flow of information on the internet, the increase in live broadcasts and incorporation of digital tools' potential, have made this newscast, on the air for almost 20 years, a type of laboratory for the network's other newscasts. And this newscast launched one of the main novelties of local Brazilian TV journalism: the program Partner of Rio produced by citizen-reporters 
from different communities hired temporarily by the channel and guided by its journalists. As the Globo Network itself defines it, Partners of Rio "is a program of RJTV which shows the reality of different regions in the metropolitan region of Rio from the point of view of the residents themselves. It is they who present the place in which they live, with a view that only they have, producing content for the newscast ${ }^{10}$.

The project was born in the Rio de Janeiro affiliate, but has already been and continues to be, incorporated by the network's newscasts in other cities of the country. This program affords the audience symbolic mobility: going from the role of reception to that of production. In an earlier work (BECKER, 2012b), it was confirmed that reporting has helped to provide a broader perception of Rio de Janeiro's geography, the state's socio-economic and cultural situations, and of the population in different municipalities, proposing a less prejudiced approach to slum dwellers. At certain points, their aspirations are effectively legitimized by means of testimony that expresses their claims and rights. However, their identities are still diffuse on the TV screen, oscillating between apprentice reporters and active representatives of the residents. They are diluted in the body of the TV newscast because the discourse of the televised newscast gives more importance to itself as the main social actor and the need for its existence, than to the population in the performance of its mediations.

There is little innovation in form or content in the editing of the reporting, which follows the same model of the reporting produced by the RJTV team. Most of the testimony in these stories still restricts the citizen to the role of unprotected victim, attributing to the population fragility in enunciation, capable of being overcome only by the intervention of TV as a supra-institutional power and with unquestionable credibility. The ways in which these enunciations are developed in the narrative of this reporting in Partners of Rio, as in the case of other RJTV stories, uphold the notion that the establishment of a complicity with television and a link with the TV newscast, are the only opportunity for poorer individuals to achieve citizenship.

The possibility to send suggestions regarding the agenda, texts and/or photos and moving images via the internet, or to disseminate videos produced by users - television viewers, increases the importance of the G1 portal, one of the most accessed in the country" "You" on G1 (http://g1.globo.com/vc-no-g1/) is the section devoted to receiving and making available the users' contributions. But collaborators are called upon to contribute in conditions which favor the sending of rather 
short texts, and preferably brief records of instantaneous, on the spot occurrences, as made clear in the section's call for material published on the site itself ${ }^{12}$.

It is noted that the possibility for user participation in the development of the news is limited. What the site calls "your news" is composed only of photos or audiovisual fragments of events, unaccompanied by information or interpretation that add more angles and approaches to the social facts. These brief records are often inserted using specific framings constructed by the journalists themselves, whether on television or the portal, only as illustrative material for their narratives.

In TV newscasts they are identified as images from amateur filmmakers, but the names of the producers of these records are not highlighted. On portals, they are referred to only as "reader", "internet user" and/or "resident", without identification of their social function. In this way, the value of the collaborative contents and formats in the development of the news is reduced, even though the available digital tools could be utilized in more authorial and opinionative, fashion.

From October 15 to 31,2011 , only two collaborative videos ${ }^{13}$ were made available. The comments published were signed but many have no informative value, while others represent invitations for the reporting team to record a specific event in order to try to resolve problems of different communities, as allies of the population in the defense of its rights in the face of the authorities' neglect.

In the "learn more" section, contents supplementing the published stories are gathered, for the most part composed of invitations to participate in the "You on G1" section, photos without subtitles, reporting previously disseminated across Globo Television Network newscasts, a company of the same media group, or just images of these same reports without audio.

In addition, the utilization of multimedia resources is rare. In a report on the implementation of exclusive corridors for circulation of buses in the south zone of the city ${ }^{14}$, for example, there is a prompt in the "learn more" section for a link to another report published on the portal a few days before with a link to the "complete map" of bus lines which would circulate in the preferential lanes ${ }^{15}$. But upon clicking on this link (http://estaticog1.globo.com/2011/10/08/FOLHETOBRSLeblonlpanemavalendo.pdf ), all that appears is a booklet published by the municipal government itself. In fact, most of the news made available on G1 does not feature video, while most of the reports that use audiovisual language originate 
from the televised newscasts.

In the period analyzed, of the 611 stories made available by the portal, only 224 are published in video, with 137 being reporting of the RJTV newscast, representing $61 \%$ of this news site's audiovisual production. The TV station's other newscasts constitute $36 \%$ of the audiovisual content, a total of 80 videos, and the portal produces only $3 \%$ of original content, just 7 videos. RJTV not only contributes most of the local production but also produces a type of agenda-setting for the production of local news in the digital environment, according to this quantitative and qualitative analysis.

There is a tendency on the part of $\mathrm{Gl}$ to create a hierarchy for the sections and topics covered in the portal, in the same way that news is produced on television. The program Partner of Rio and the section You on $\mathrm{G} 1$ are the environments in which the audience's participation is expressed in a more significant way on this news site. Nevertheless, one also notes that the reports in Partners of Rio do not even represent $2 \%$ of the contents of the site. On RJTV, this percentage is four times higher, even though it represents less than $10 \%$ of the newscast's production of reports.

\section{The refutation of a myth}

This study of the local production of news by the RJTV newscast and the G1 portal reveals that the constant prompting of TV viewers to participate in the development of the news, has not contributed to the construction of higher quality audiovisual journalistic narratives. The news contents and formats broadcast on TV and made available on the internet tend to be more uniform and result more from an attempt to get around the reduction of profits "forming more flexible and leaner teams capable of producing differentiated contents adaptable to various media" (LUZ, 2010, p. 4), rather than from efforts to produce more plural, contextualized reports of events with more esthetic creativity. Collaborative production in video, provided by convergence, still serves more as an illustration of stories produced by journalists than as contents and formats offering other angles and points of view in the transformation of social events into news, collaborating in providing a greater awareness of historic reality. It becomes clear in this analysis that the available digital tools and technologies are not in themselves sufficient for making journalistic practices more diverse, but rather for their utilizations. Relations with the audience are more dialogical in the 
televised newscast than on the information site of the country's largest media group because, in some ways, the communities' representatives assume the position of journalism co-workers (HEINONEN, 2011). This does not mean there is symmetry between producers and TV viewers capable of providing social discourses that are more revealing of contemporary contradictions, collaborating in affording greater comprehension of reality. TV viewers play a more active role but the reports are not fully polyphonic, made up of otherness, the exchange of experiences, of visions and sensitivities, because they follow the pattern of the TV station's regional journalism.

Despite the fact that the entire social structure can be seen as a network of dialogues and discourses, the equilibrium between the two is a utopia (FLUSSER, 2009), which should still be aspired to for the purposes of perfecting journalistic practices. Journalism is beginning to redesign forms of establishing interactions and partnerships with voices that are outside the media, starting with the experiences of the social media, which already take the form of a place for resonance of multiple perceptions, of social struggle and resistance, and often of entertainment, and which can no longer be ignored in the development of the news because it is precisely in the search for a better connection with audiences that journalism can reinvent itself. The incorporation of citizens' contributions in factual news production is still not very expressive but can be done in different and innovative ways. One possibility would be the development and implementation of dedicated platforms for the inclusion of collaborative content and more expanded and diverse formats, bringing together different points of view and controversial testimony about an event without presenting a single truth. There is still much to be explored by seeking in the responsive attitude of the users-TV viewers, more interactive means of news construction for journalism to set itself up as a broader form of knowledge and comprehension of the world. It is especially important to observe the ways in which the I and the other are constructed and represented in the news, which has so much influence on the creation of bonds and identities of individuals and social groups.

However, the exercise of a higher quality audiovisual journalism also entails the improvement of journalism education through interdisciplinary training. It is true that the training of future professionals should lie more in grasping the ethical principles of journalism practice than in the mastery of production techniques and management of information, or of the equipment for receiving and 
editing audiovisual contents. But universities need to offer students opportunities for developing inventive, quality editorial products, taking maximum advantage of digital media's enormous potential for communication, which does not mean only offering technical training in these tools but also encouraging students to exploit the communicative potential of the new languages, so that future professionals can produce stories for several platforms in multiple formats (SALAVERRÍA and NEGREDO, 2011; LUZ, 2010). In the advent of new forms of writing in the digital environment, characterized by greater audience participation, the hybridization of languages and transmediality, the teaching of journalism should stimulate increasingly critical and creative uses of audiovisual media and information technologies.

\section{NOTES}

1 As Ong (1988) explains, the differences between orality and writing have been much discussed by experts in recent decades. Language studies tend to focus on writing, suggesting that oral texts are less complex. However, if the spoken language can exist without writing, the opposite is not true. Thoughts and emotions are also expressed only through sound. According to Ong (idem), writing can be understood as a complementary form of communication to orality. Logan (2012: p81) suggests that "although the written language is derived from the spoken language, it is helpful to consider them as two distinct modes of language, because they process information in very different ways". In his studies on the evolution of language, the author states that these various modes of language provide specific frameworks to view and understand the world (Logan, 2012). The author also claims that today, language corresponds to the sum of the communication processes with information technology. He shows that a new language always emerges as a response to the chaos caused by the saturation of information that earlier languages have failed to address (2010). It can already be seen that the use of the computer, internet, and digital tools in social life makes possible hybrid forms of expression and communication formed by different combinations of words, pictures, videos and audios. These unique languages are beginning to coexist in exchanges of messages marked as much by orality as writing that can be shared collectively in environments where consumers can assume the role of producer. For these reasons, the emergence of a new, developing phase of orality is mentioned. 
2 Many terms have been used to describe participatory journalism, also called collaborative journalism, citizen journalism or produsage (Bruns, 2011). The definition accepted here is that of Bowman \& Willis (2003), who define participatory journalism as an action of a citizen or group of citizens who play an active role in the process of collecting, reporting, analyzing and disseminating information in an independent way. As Singer (2011) suggests, this choice is justified because the expression "participatory journalism" involves a collaborative, collective action, not just parallel to the journalistic production of large media groups.

3 Syncrisis represented the confrontation of different points of view with regard to a specific subject, and anacrisis referred to the methods by which the interlocutor's words were stimulated, leading them to express their opinion (2002).

4 Conversion made according to the foreign exchange table of the Brazilian Central Bank available at: http://www4.bcb.gov.br/pec/conversao/conversao.asp

5 idem

6 Dates identified in the Table of Costs in Effect in the National Market, based on viewer ratings measured by the Brazilian Institute of Public Opinion and Statistics (IBOPE), systematized and made available by the advertising agencies for advertisers referring to the insertions of advertisements from April 1 to September 30, 2012.

7 Data available at (http://www.projetointermeios.com.br/relatorios/rel_ investimento_3_0.pdf; http://www.telaviva.com.br/Revista.aspx - Ano 21-\#224- mar.2012, p.12-13.).

8 Attempts to take advantage of the audiences `collaborative participation in news construction have occurred in the practice of "public" or "civic" journalism since the end of the 1980s and beginning of the 1990s, but the availability of news in social media almost in real time, the continual multiplication of channels available for the publication and dissemination of news, and the development of collaborative models for the participation of users and for the creation of content, have accelerated theses changes (BRUNS, 2011).

9 Available at: http://g1.globo.com/rio-de-janeiro/parceiro-rj/noticia/2011/11/ inscreva-se-para-ser-o-parceiro-do-rj-na-rocinha.html.

10 Available at: http://www.alexa.com/topsites/countries/BR

11 Available at: VC no G1: está no local? Envie fotos ou vídeo 
12 Available at: http://g1.globo.com/rio-de-janeiro/noticia/2011/10/bombeiroscontrolam-incendio-em-camelodromo-no-rio.html ; http://g1.globo.com/rio-dejaneiro/noticia/2011/10/apos-incendio-em-veiculos-faixas-da-avenida-brasil-saoliberadas.html.

13 Available at: http://g1.globo.com/rio-de-janeiro/noticia/2011/10/corredor-brs-nocentro-do-rio-comeca-funcionar-em-dezembro.html.

14 Available at: http://g1.globo.com/rio-de-janeiro/noticia/2011/10/comeca-operarsegundo-corredor-de-onibus-em-ipanema-e-leblon.

\section{REFERENCES}

BAKHTIN, Mikhail. Problemas da poética de Dostoiévski. 3 ed. Rio de Janeiro: Forense Universitária, 2002.

Fontes, 2006.

Estética da Criação Verbal. São Paulo: Martins

BECKER, Beatriz. Midia e Jornalismo como formas de Conhecimento: uma metodologia para leitura crítica das narrativas jornalísticas audiovisuais. Matrizes, Revista do Programa de Pós-Graduação em Ciências da Comunicação da Universidade de São Paulo, Vol.5, № 2. São Paulo: ECA/USP, $2012 \mathrm{a}$.

Todos juntos e misturados, mas cada um no seu quadrado: um estudo do RJTV $1^{\text {a }}$ edição e do Parceiro do RJ. XXI Encontro Anual da COMPós 2012 (Associação Nacional dos Programas Pós-Graduação em Comunicação), GT Estudos de Jornalismo, UFJF, 2012b Avaiable at : http://www.compos.org.br/

\section{Jornalismo audiovisual de qualidade: um}

conceito em construção, Estudos em Jornalismo e Mídia. Vol. 6, No. 2, 2009. Available at: http://www.periodicos.ufsc.br/index.php/jornalismo/ article/view/11336.

A linguagem do Telejornal, um Estudo da Cobertura dos 500 Anos do Descobrimento do Brasil. Rio de Janeiro: E-papers, 2005.

; LIMA, Marcos Henrique. Ame ou Deixe o Ciberespaço. In: Estudos em Jornalismo e Mídia. Ano IV - n. 2 - p. 11 a 23 - July/ Dcc. 2007.

BECKER, Beatriz; MALDONADO, Oscar. Reconfigurações da mediação jornalística na contemporaneidade: Processos colaborativos de construção de 
notícias no CNN iReport \& NowPublic. Estudos de Comunicação/ Communication Studies, Vol.9, May 2011. Available at: http://www.ec.ubi.pt/ec/09/pdf/EC092011Mai-11.pdf

_; MATEUS, Lara. Pensando e fazendo wejornalismo audiovisual: a experiência do TJUFRJ. Observatorio (OBS*), ISSN 1646-5954, Vol 5, série 1, p. 059-075, 2011 , Available at : http://obs.obercom.pt/index.php/obs ; http://obs.obercom.pt/index.php/obs/article/view/475/415

\section{O Melhor Telejornal do Mundo: um exercício}

televisual. In: VIZEU, Alfredo; PORCELLO, Flávio; COUTINHO, Iluska ( orgs.). 60 Anos de Telejornalismo no Brasil, história, análise e crítica. Florianópolis: Editora Insular, 2010.

; TEIXEIRA, Juliana. Um panorama da produção

jornalística audiovisual no ciberespaço: as experiências das redes colaborativas. Revista FAMECOS, Vol.1, n40. Porto Alegre: 2009a. Available at: http://revistaseletronicas.pucrs.br/ojs/index.php/ revistafamecos/article/view/6316

Narrativas jornalísticas audiovisuais: um estudo dos efeitos da convergência no JN e no UOL. Revista Galáxia, São Paulo, n. 18, p.232-246, 2009b. Available at: http://revistas.pucsp.br/ index.php/galaxia/article/view/2686/1733

BRUNS, Axel. Gatekeeping, Gatewatching, Realimentação em Tempo Real: novos desafios para o Jornalismo. Brazilian Journalism Research, Vol.7, N2., 2011 . Available at: http://bjr.sbpjor.org.br/bjr/article/ view/342/315

BOWMAN, Shayne; WILLIS, Chris, We Media: How audiences are shaping the future of news and information, The Media Center at the American Press Institute, Reston, 2003. Available at : http://www. hypergene.net/wemedia/download/we_media.pdf

CERTEAU, Michel de. A Invenção do Cotidiano. $2^{\mathrm{a}}$. ed. Petrópolis, RJ: Vozes, 1996.

LUZ, Andréa Aparecida da. Cenário de convergência, impactos no webjornalismo e o caso Clarín.com. Intercom - Sociedade Brasileira de Estudos Interdisciplinares daComunicação, XI Congresso de Ciências da Comunicação na Região Sul - Novo Hamburgo - RS, 2010. Available at: http://www.intercom.org.br/papers/regionais/sul2010/resumos/ R20-1091-1.pdf

DOMINGO, David et al. Four Dimensions of Journalistic Convergence: A preliminary approach to current media trends at Spain, 2007. Available at: http://online.journalism.utexas.edu/2007/papers/ Domingo.pdf.

JENKINS, Henry. Cultura da convergência. São Paulo: Aleph, 2008. 
et al. Confronting the Challenges of Participatory Culture, Media Education for the 21 st Century. Cambridge, Massachusetts: The MIT Press, 2009.

FAIRCLOUGH, Norman. Discurso e mudança social. Brasília: UNB, 2001.

FLUSSER, Vilém. A escrita- Há futuro para a escrita? São Paulo: Annablume, 2010.

\section{O universo das Imagens Técnicas: elogia da}

superficialidade. $2^{\mathrm{a}}$ ed. São Paulo: Annablume, 2009.

IN: Cardoso, Rafael (org.). O Mundo Codificado. $1^{\text {a }}$ ed. São Paulo: Cosac Naify, 2007. p. 90-94.

HEINONEN, Ari. The Journalist's Relationship with Users: New dimensions to conventional roles. In: SINGER, Jane $B$. et al.

Participatory Journalism: guarding open gates at online newspapers. Oxford, UK: Wiley-Blackwell, 2011

HERMIDA, Alfred. Mechanisms of Participation: How audience options shape the conversation. In: SINGER, Jane B. et al.

Participatory Journalism: guarding open gates at online newspapers. Oxford, UK: Wiley-Blackwell, 2011.

LOGAN, Robert K. Understanding New Media, Extending Marshall Mc Luhan, New York: Peter Lang Publishing, 2010.

O que é a informação? A propagação da

organização da biosfera, na simbolosfera, na tecnosfera e na econosfera. Rio de Janeiro: PUC-Rio, 2012.

MACHADO, Arlindo. A televisão levada a sério. São Paulo: SENAC, 2003.

MARTÍN-BARBERO, Jesús. Desafios culturais: da comunicação à educação. In: CITELLI, Adilson; COSTA, Maria Cristina Castilho. Educomunicação, construindo uma nova área de conhecimento. São Paulo, Paulinas, 2011.

ONG, Walter J.. Orality and Literacy, The technologizing of the world. New York: Routledge, 1988.

PAVLIK, John V. A tecnologia Digital e o Jornalismo: as implicações para a democracia. Brazilian Journalism Research, Vol.7, N.2, 2011. Available at : http://bjr.sbpjor.org.br/bjr/article/view/340/314

QUANDT, Thorsten. Undestanding a new Phenomenon: the significance of participatory Journalism. In: SINGER, Jane B. et al. Participatory Journalism: guarding open gates at online newspapers. 
Oxford, UK: Wiley-Blackwell, 2011

RAMOS, Daniela Osvald. Aspectos da convergência de mídias e da produção de conteúdo multimídia no Clarín.com . Líbero, v. 13, n. 25, São Paulo, 2010 . Available at:http://www.casperlibero.edu.br/ rep_arquivos/2010/08/02/1280783041.pdf

SALAVERRÍA, R .Online Journalism Meets The University: ideas for teaching and research. Brazilian Journalism Research, v.7, n.2, 2011 . Avaiable at: http://bjr.sbpjor.org.br/bjr/article/view/356

SALAVERRÍA, Ramon.; NEGREDO, Samuel. Periodismo integrado: convergencia de medios y reorganización de redacciones.

Barcelona: Editorial Sol90 Media, 2009.

SINGER, Jane B. et al. Participatory Journalism: guarding open gates at online newspapers. Oxford, UK: Wiley-Blackwell, 2011

STAM, Robert. Bakhtin: da Teoria Literária à Cultura de Massa. São Paulo: Ática, 1992.

SCOLARI, Carlos Alberto. Ecología de la hipertelevisión.

Complejidad narrativa, simulación y trasmedialidad en la televisión contemporánea. In: Televisão Digital, desafios para a comunicação, SQUIRRA, Sebastião; FECHINE, Yvana (orgs.), Porto Alegre, Sulina, 2009.

TRAQUINA, Nelson. Teorias do Jornalismo, vol.II, Editora Insular, Florianópolis/SC, 2005.

VILCHES, Lorenzo. Manipulación de la Informacion Televisiva, Ediciones Paidós, Barcelona, 1995. 
CONVERGENCE VS DIVERSITY

BRAZILIANJOURNALISM RESEABCH-Volume 8-number a- zOIa| 63 